\title{
Short-Term Effects of Air Pollution on Coronary Events in Strasbourg, France-Importance of Seasonal Variations
}

\author{
Baptiste Vaudrey ${ }^{1, *}$, Marie Mielcarek ${ }^{2}$, Erik Sauleau ${ }^{2}$, Nicolas Meyer ${ }^{2}$, Benjamin Marchandot ${ }^{1}$, \\ Marie Moitry ${ }^{3}$, Pierre Robellet ${ }^{4}$, Thierry Reeb ${ }^{5}$, Laurence Jesel ${ }^{1,6}$, Patrick Ohlmann ${ }^{1}$, \\ Thomas Bourdrel ${ }^{5}$ and Olivier Morel ${ }^{1,6}$ \\ 1 Pôle d'Activité Médico-Chirurgicale Cardio-Vasculaire, Nouvel Hôpital Civil, \\ Centre Hospitalier Universitaire, Université de Strasbourg, 67091 Strasbourg, France; \\ benjamin.marchandot@gmail.com (B.M.); laurence.jesel-morel@chru-strasbourg.fr (L.J.); \\ patrick.ohlmann@chru-strasbourg.fr (P.O.); olivier.morel@chru-strasbourg.fr (O.M.) \\ 2 GMRC, Service de Santé Publique, Centre Hospitalier Universitaire de Strasbourg, 67091 Strasbourg, France; \\ marie.mielcarek@chru-strasbourg.fr (M.M.); Erik.SAULEAU@chru-strasbourg.fr (E.S.); \\ nicolas.meyer@chru-strasbourg.fr (N.M.) \\ 3 Department of Public Health, Strasbourg University Hospital, 67091 Strasbourg, France; mmoitry@unistra.fr \\ 4 Pôle exploitation-Unité Surveillance réglementaire, ATMO Grand EST; association à but non lucratif agréée \\ par le Ministère chargé de l'environnement, 67300 Schiltigheim, France; pierre.robellet@atmo-grandest.eu \\ 5 Clinique Rhéna, 67000 Strasbourg, France; t.reeb@medecin-alsace.fr (T.R.); thomasbourdrel@yahoo.fr (T.B.) \\ 6 UMR INSERM 1230 Regenerative Nanomedicine, University of Strasbourg, 67000 Strasbourg, France \\ * Correspondence: baptiste.vaudrey@yahoo.fr
}

Received: 2 February 2020; Accepted: 15 July 2020; Published: 7 August 2020

check for updates

\begin{abstract}
The aim of this study, is to investigate the effects of a short-term exposure to air pollutants, as assessed by Nitrogen dioxide $\left(\mathrm{NO}_{2}\right)$, Particulate Matter $\mathrm{PM}_{2,5}$ and $\mathrm{PM}_{10}$ concentrations, on coronary event onsets in Strasbourg, France. An observational, analytical, retrospective, epidemiological study was conducted in Strasbourg between 1 January 2012 and 31 December 2014. Higher daily coronary events rates were evidenced when $\mathrm{NO}_{2}$ concentrations were measured above $40 \mu \mathrm{g} / \mathrm{m}^{3}$ (1.258 (95\% CI 1.142-1.374) vs. 1.110 (95\% CI 1.033-1.186); $p=0.015)$. The $\mathrm{NO}_{2}$ concentration was higher than $30 \mu \mathrm{g} / \mathrm{m}^{3}$ for 677 days $(61.8 \%)$. Higher daily coronary events rates were evidenced when $\mathrm{NO}_{2}$ concentrations were measured above $30 \mu \mathrm{g} / \mathrm{m}^{3}$ (1.208 (95\% CI 1.128-1.289) vs. 1.067 (95\% CI $0.961-1.172) p=0.009$ ). A marked seasonality of $\mathrm{NO}_{2}, \mathrm{PM}_{2.5}$, and $\mathrm{PM}_{10}$ concentrations characterized by an increase during winter and a decrease during the summer could be established. The seasonality of coronary events was evidenced simultaneously. After adjustments were made to account for the time and the month, no independent impact of $\mathrm{NO}_{2}, \mathrm{PM}_{2.5}$ or $\mathrm{PM}_{10}$ on daily coronary events could be demonstrated.
\end{abstract}

Keywords: air pollution; acute coronary syndrome; $\mathrm{NO}_{2} ; \mathrm{PM}_{2.5} ; \mathrm{PM}_{10}$; seasonality

\section{Introduction}

Although numerous epidemiological studies have uncovered noxious associations between the air pollution and the cardiovascular mortality burden, the recognition of air pollution as a silent killer remains largely unknown by the cardiology community. Ref. [1-3] Various projections have estimated that outdoor air pollution may be responsible of 3.3 million premature deaths per year worldwide, predominantly in Asia. Ref. [4,5] While the relationship between air pollution and the atherothrombotic burden appears to be likely, the precise mechanisms underlying their association are 
not fully understood. Previous data has underlined that the air pollution could be associated with key markers of the atherothrombotic burden, including systemic inflammatory response, oxidative stress, endothelial dysfunction, blood coagulation that could pave the way for plaque rupture, and thrombus formation. Air pollution can be divided into two types: gaseous substances and materials particulate. The main gases studied herein are nitrogen oxides $\left(\mathrm{NO}_{\mathrm{x}}\right)$ including nitrogen dioxide $\left(\mathrm{NO}_{2}\right)$ and nitrogen monoxide $(\mathrm{NO})$, carbon monoxide $(\mathrm{CO})$, and ozone $\left(\mathrm{O}_{3}\right)$. The main source of $\mathrm{NO}_{\mathrm{x}}$ emissions is the combustion of fossil fuels. Road transport remains an important source of $\mathrm{NO}_{\mathrm{x}}$ production worldwide, especially when diesel vehicles are used. Particles are classified according to their aerodynamic diameter. The usual distinction was made between the "coarse" particles called $\mathrm{PM}_{10}$ (diameter $<10 \mu \mathrm{m}$ ), $\mathrm{PM}_{2.5}$ or fine particles (diameter $<2.5 \mu \mathrm{m}$ ), and ultrafine particles also called nanoparticles $\left(\mathrm{PM}_{0.1}\right.$, diameter $\left.<0.1 \mu \mathrm{m}\right)$. The sources of anthropogenic emissions of $\mathrm{PM}_{10}$ and $\mathrm{PM}_{2.5}$ lie with various sectors including the agricultural, the residential, the tertiary, the industrial, and the transport sectors. While a minority of studies suggests an increase in the risk of acute coronary syndromes following exposure to elevated $\mathrm{O}_{3}$ concentrations, the impact of short-term exposure to $\mathrm{NO}_{2}, \mathrm{PM}_{2.5}$, and $\mathrm{PM}_{10}$ on myocardial risks appears to be more consistent [6-11]. For example, Bhaskaran et al. in a meta-analysis have noticed that $\mathrm{PM}_{2,5}$ was associated with an incremental risk of myocardial infarction (from $5 \%$ to $17 \%$ per $10 \mu \mathrm{g} / \mathrm{m}^{3}$ increase), $\mathrm{PM}_{10}$ was associated with an incremental risk of myocardial infarction $\left(0.7-11 \%\right.$ per $\left.10 \mu \mathrm{g} / \mathrm{m}^{3}\right)$ and $\mathrm{NO}_{2}$ also $(1-9 \%$ per $10 \mathrm{ppb})$. In order to protect vulnerable populations, various warning thresholds have been defined by regulatory agencies. For example, European recommendations indicate that the annual $\mathrm{NO}_{2}$ rate should not exceed $40 \mu \mathrm{g} / \mathrm{m}^{3}$. The recommendation and information threshold for the population is triggered when $\mathrm{NO}_{2}$ rate is greater than or equal to $400 \mu \mathrm{g} / \mathrm{m}^{3}$ on an hourly average, for 3 consecutive hours.

For $\mathrm{PM}_{10}$, the annual average not to be exceeded is $40 \mu \mathrm{g} / \mathrm{m}^{3}$. for $\mathrm{PM}_{2.5}$, the annual average not to be exceeded is $25 \mu \mathrm{g} / \mathrm{m}^{3}$.

However, these recommendation and information threshold appears to be very high and is not encountered frequently in daily practice in European countries.

In the present study, we aim to investigate the effect of short-term exposure of air pollutants as assessed by Nitrogen dioxide $\left(\mathrm{NO}_{2}\right)$, Particulate Matter (PM) in $\mathrm{PM}_{2.5}$ and $\mathrm{PM}_{10}$ concentrations on coronary event onsets in Strasbourg, France. In addition, seasonality of air pollution and of coronary events is also studied.

\section{Materials and Methods}

\subsection{Population Studied}

The study was restricted to the inhabitants of Strasbourg. In 2014, Strasbourg had 276,170 inhabitants in an area spanning $78.3 \mathrm{~km}^{2}$. Ref. [12] Strasbourg city is located in the North East of France ("Region Grand Est"), close to the German border (latitude 48.5734053, longitude 7.7521113).

\subsection{Cases}

The cases were defined as coronary events, either fatal or non-fatal, in men and women, occurring in the age group of 35-74 years, between 1 January 2012 and 31 December 2014. These cases were identified by the MONICA registry [13]. To safeguard the anonymity of the patients involved, no meaningful clinical information (sex categories, age, cardiovascular risk factors, etc.) could be recorded. There were no exclusion criteria.

\subsection{Assessment of Exposure to Air Pollution}

Data on daily air pollution was collected from ASPA (now called «Atmo Grand Est»), which is a non-profit organization labelled by the Ministry of the Environment, which is in charge of air quality monitoring in the «Region Grand Est». Daily air pollution was assessed using $24 \mathrm{~h}$ average $\mathrm{NO}_{2}$, $\mathrm{PM}_{10}$, and $\mathrm{PM}_{2.5}$ concentrations. Three fixed stations in Strasbourg city were used to measure the air 
pollution. Strasbourg North: measurement of $\mathrm{NO}_{2}, \mathrm{PM}_{10}$; Strasbourg East: measurement of $\mathrm{NO}_{2}$ and $\mathrm{PM}_{2.5}$; Strasbourg CLEMENCEAU (Traffic zone): measurement of $\mathrm{NO}_{2}$ and $\mathrm{PM}_{10}$. For simplicity's sake, the daily measurements of $\mathrm{NO}_{2}$ in the stations North, East and CLEMENCEAU were averaged. Similarly, the daily measurements of $\mathrm{PM}_{10}$ in the stations North and East were averaged as well.

\subsection{Seasonality}

Strasbourg city has a semi-continental climate with a warm summer (July $19.2{ }^{\circ} \mathrm{C}$ ) and a cold winter (January $0.9^{\circ} \mathrm{C}$ ). Four time periods were considered: winter for the months of January, February, March; spring for the months of April, May, June; summer for the months of July, August, September; and fall (autumn) for the months of October, November, and December.

\subsection{Lags}

As plaque rupture can cause immediate or sometimes delayed clinical manifestations of acute coronary syndromes due to dynamic thrombotic response, several lags between air pollution and myocardial infarction (MI) events were investigated: the average of the day preceding the coronary event (lag Day-1), the average of the day which preceded the coronary event by 2 days (lag Day-2), the average of the day which preceded the coronary event by 3 days (lag Day-3).

\subsection{Statistical Analysis}

This was an epidemiological, observational, analytical, and retrospective study. The descriptive statistical analysis of the quantitative variables was done by indicating the position parameters (average, median, minimum, maximum, first, and third quartiles), as well as the dispersion parameters (variance, standard deviation, range, interquartile range) for each variable. The Gaussian character of the data was tested by the Shapiro-Wilk test. The description of the qualitative variables was done by providing the numbers and proportions of each category in the sample. The comparison of quantitative variables between groups was performed either by a Student's test (when the variable of interest was Gaussian) or by a nonparametric test in the opposite case (Mann-Whitney-Wilcoxon test). Generalized additive models (GAM) were used for the inferential analysis. They make it possible to process count data and to produce a smoothing of the effect of the explanatory variables.

\section{Results}

\subsection{Number and Categories of Coronary Events}

In total, 1265 coronary events were recorded between 1 January 2012 and 31 December 2014 (1096 days). The daily coronary event rate was 1.154/day on average. Diagnostic categories of coronary events and the daily repartition are shown in Tables 1 and 2.

Table 1. Diagnostic categories of coronary events.

\begin{tabular}{cc}
\hline Diagnostic Categories & Number of Coronary Events (\% of Total Events) \\
\hline 1 Myocardial infarction characterized & $243(19.2 \%)$ \\
2 Probable coronary death & $74(5.8 \%)$ \\
3 Sudden death in less than $24 \mathrm{C}$ & $172(13.6 \%)$ \\
4 Acute Coronary Syndrome & $443(35 \%)$ \\
5 Unstable angina & $159(12.6 \%)$ \\
6 Other acute form of ischemic heart disease & $174(13.9 \%)$ \\
\hline
\end{tabular}


Table 2. Number of daily coronary events.

\begin{tabular}{cc}
\hline Daily Coronary Events & Days (\%) \\
\hline 0 & $353(32.2 \%)$ \\
1 & $372(33.9 \%)$ \\
2 & $261(23.8 \%)$ \\
3 & $83(7.6 \%)$ \\
4 & $18(1.6 \%)$ \\
5 & $6(0.5 \%)$ \\
6 & $2(0.2 \%)$ \\
7 & 0 \\
8 & $1(0.1 \%)$ \\
\hline
\end{tabular}

\subsection{Pollutants}

The air pollution data is illustrated in Table 3. Mean and range of the air pollutant studied in Strasbourg was comparable to that shown in a previous report made in the same Strasbourg Metropolitan Area [14].

Only very little data was missing $\left(\mathrm{NO}_{2}: 0 \%, \mathrm{PM}_{2.5}: 5.47 \%\right.$ (60 days), $\mathrm{PM}_{10}: 0.27 \%$ (3 days)).

Table 3. Daily concentrations of air pollutants $\left(\mu \mathrm{g} / \mathrm{m}^{3}\right)$.

\begin{tabular}{ccccccccc}
\hline Pollutant & Mean & SD & Min & Q1 & Med & Q3 & Max & IQR \\
\hline $\mathrm{NO}_{2}$ & 34.68 & 12.53 & 9.67 & 25.33 & 33.33 & 41.67 & 92.67 & 16.33 \\
$\mathrm{PM}_{2.5}$ & 17.49 & 10.60 & 2 & 10 & 15 & 22 & 66 & 12 \\
$\mathrm{PM}_{10}$ & 23.82 & 13.30 & 5,5 & 14 & 21.5 & 30.5 & 87.5 & 16.5 \\
\hline
\end{tabular}

SD = standard deviation, Min = Minimum, Q1 = Quartile 1, Med = Median, Q3 = Quartile 3, Max = Maximum, $\mathrm{IQR}=$ Interquartile Range.

\subsection{Impact of the $\mathrm{NO}_{2}$ Concentration on Coronary Events}

The $\mathrm{NO}_{2}$ concentration was higher than $40 \mu \mathrm{g} / \mathrm{m}^{3}$ on 329 days (30\%). Higher daily coronary events rates were evidenced when $\mathrm{NO}_{2}$ concentrations were measured above $40 \mu \mathrm{g} / \mathrm{m}^{3}(1.258(95 \% \mathrm{CI}$ $1.142-1.374)$ vs. $1.110(95 \% \mathrm{CI} 1.033-1.186) ; p=0.015)$. The $\mathrm{NO}_{2}$ concentration was higher than $30 \mu \mathrm{g} / \mathrm{m}^{3}$ on 677 days $(61.8 \%)$. Higher daily coronary events rates were evidenced when $\mathrm{NO}_{2}$ concentrations were measured above $30 \mu \mathrm{g} / \mathrm{m}^{3}$ (1.208 (95\% CI 1.128-1.289 vs. 1.067 (95\% CI 0.961-1.172) $\left.p=0.009\right)$.

\subsection{Impact of the $P M_{2.5}$ Concentration on Coronary Events}

The $\mathrm{PM}_{2.5}$ concentration was higher than $25 \mu \mathrm{g} / \mathrm{m}^{3}$ on 191 days (17.4\%). No impact of a $\mathrm{PM}_{2.5}$ concentration above $25 \mu \mathrm{g} / \mathrm{m}^{3}$ on the daily coronary event rate could be established (>25 $\mu \mathrm{g} / \mathrm{m}^{3}: 1.168$ (95\% 1.031-1.304) vs. $<25 \mu \mathrm{g} / \mathrm{m}^{3}: 1.151$ (95\% CI 1.079-1.223); $\left.p=0.407\right)$.

\subsection{Impact of the $P M_{10}$ Concentration on Coronary Events}

The $\mathrm{PM}_{10}$ concentration was higher than $40 \mu \mathrm{g} / \mathrm{m}^{3}$ on 123 days $(11.2 \%)$. No impact of a $\mathrm{PM}_{10}$ concentration above $40 \mu \mathrm{g} / \mathrm{m}^{3}$ threshold on the daily coronary event rate could be established (>40 $\mu \mathrm{g} / \mathrm{m}^{3}: 1.114$ (95\% 0.962-1.266) vs. $<40 \mu \mathrm{g} / \mathrm{m}^{3}: 1.160$ (95\% CI 1.090-1.230); $\left.p=0.950\right)$.

\subsection{The Seasonality of Coronary Events}

The daily coronary event rate was collected and analyzed for each month (Figure 1) and for each season (Figure 2), between 1 January 2012 and 31 December 2014.

The incidence of coronary events was at its highest level in the winter (January) and at its lowest level in the summer (August) $(p=0.009)$ (Figures 1 and 2). 


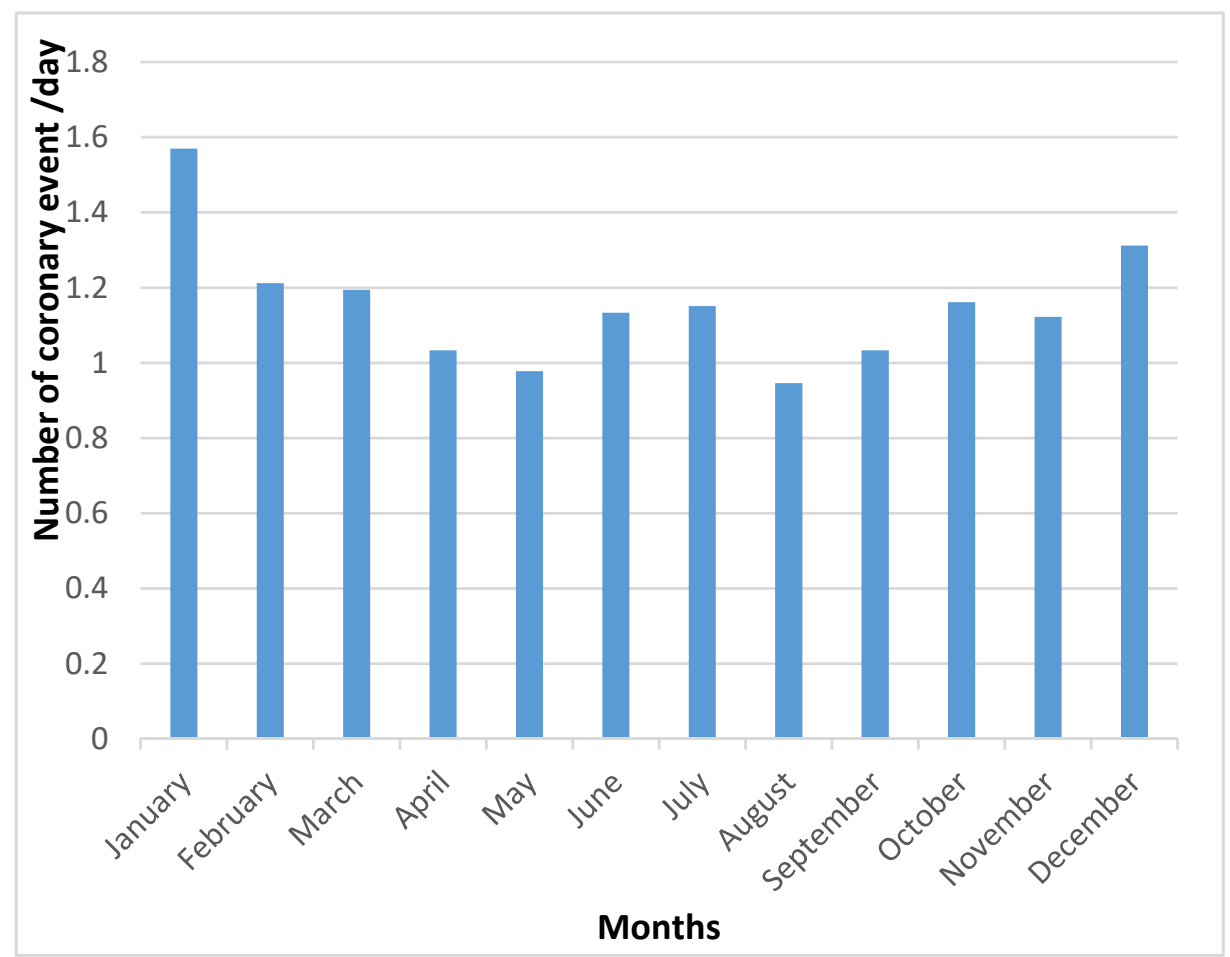

Figure 1. Daily coronary event rate for each month.

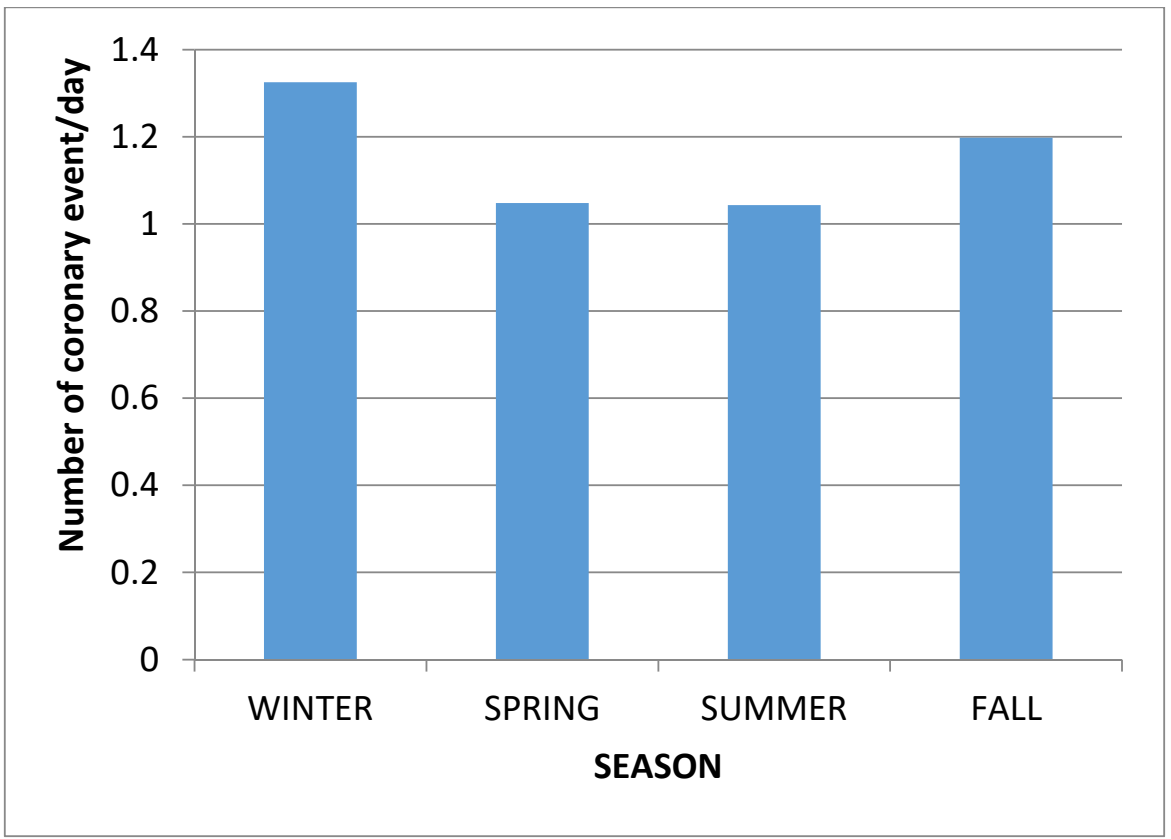

Figure 2. Daily coronary event for each season.

\subsection{Inferential Analysis: Generalized Additive Model (GAM)—Pollutant and Time Effect}

In order to address the effect of time on the concentrations of pollutant, an inferential analysis using a generalized additive model was performed. A clear seasonality of air pollutant concentration could be evidenced, with a decrease in the summer and increase in the winter. Air pollutants were at their highest levels in January and at their lowest levels in August $(p<0.001)$. Similar variations were evidenced for $\mathrm{NO}_{2}$ (Figure 3), $\mathrm{PM}_{2.5}$ and $\mathrm{PM}_{10}$.

When a time adjusted analysis was performed, no independent impact of $\mathrm{NO}_{2}, \mathrm{PM}_{2.5}$, and $\mathrm{PM}_{10}$ concentrations on daily coronary events could be demonstrated. 
No relationship between different intervals (Day-1, Day-2, Day-3) of air pollutant concentration $\left(\mathrm{NO}_{2}, \mathrm{PM}_{2.5}, \mathrm{PM}_{10}\right)$ and the onset of MI could be evidenced.

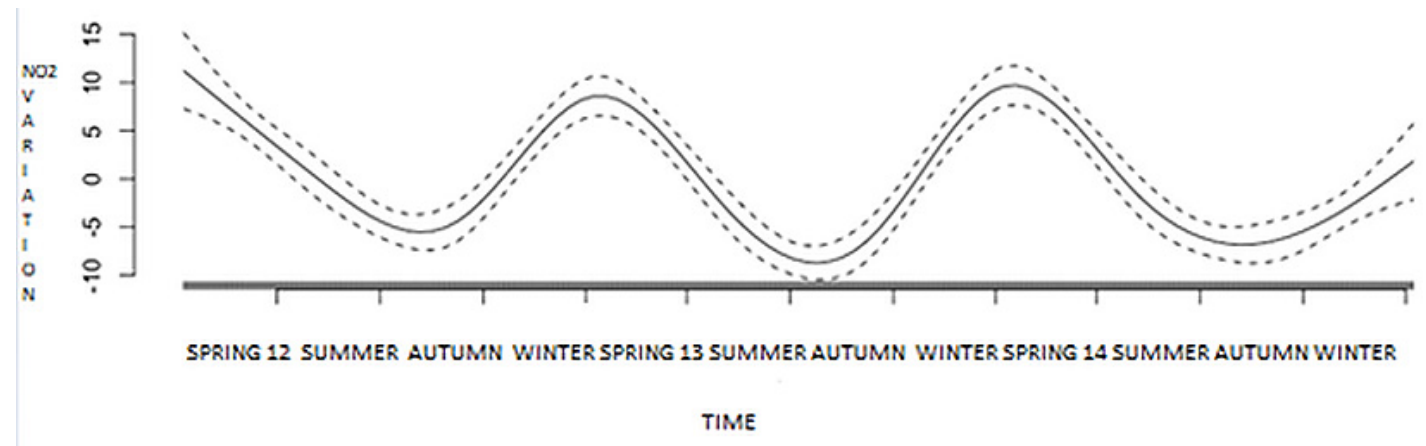

Figure 3. Time effect on $\mathrm{NO}_{2}$ concentrations.

\section{Discussion}

In the present study, the effect of a short-term exposure to air pollutants as assessed by $\mathrm{NO}_{2}, \mathrm{PM}_{2.5}$, and $\mathrm{PM}_{10}$ concentrations on coronary event onsets was examined in an urban population located in Strasbourg, France.

In Strasbourg, a continuous decline in the annual mean concentrations of $\mathrm{NO}_{2}$ can be evidenced since 2005. In 2013, road transport was still the leading cause of $\mathrm{NO}_{\mathrm{x}}$ emissions (58\%), although a significant decrease (by $44 \%$ ) of its emissions has been evidenced since the early 2000s. Possible explanations could rely on a continuous renewal of the vehicle fleet despite a significant increase in heavy goods vehicle traffic along the main highways [15]. Additionally, specific City Hall policies were developed over time to limit air pollution. For instance, a public transport network including high-frequency bus and tramway was developed, and Strasbourg had the largest cycle path network in France for many years (more than $600 \mathrm{kms} / 373$ miles). Despite continuous efforts, the inhabitants of Strasbourg were exposed to significant levels of the $\mathrm{NO}_{2}$ concentration $\left(>40 \mu \mathrm{g} / \mathrm{m}^{3}\right)$ every third day. In this metropolitan area, higher daily coronary events were recorded when $\mathrm{NO}_{2}$ concentrations peaked above $40 \mu \mathrm{g} / \mathrm{m}^{3}$. Importantly the association between daily coronary events and $\mathrm{NO}_{2}$ concentrations was even evidenced at a lower threshold $\left(>30 \mu \mathrm{g} / \mathrm{m}^{3}\right)$, which was usually considered to be safe. In Europe, different thresholds for $\mathrm{NO}_{2}$ concentrations are implemented. The mean value of $\mathrm{NO}_{2}$, as an annual mean, should not exceed $40 \mu \mathrm{g} / \mathrm{m}^{3}$, whilst the $200 \mu \mathrm{g} / \mathrm{m}^{3}$ threshold should not be exceeded for more than $18 \mathrm{~h}$ in a year. Warning information should be triggered when $\mathrm{NO}_{2}$ peaks above $400 \mu \mathrm{g} / \mathrm{m}^{3}$ for more than 3 consecutive hours. In the present study, the threshold of $200 \mu \mathrm{g} / \mathrm{m}^{3} / \mathrm{h}$ has been exceeded on 23 days (14 days in 2012, 6 days in 2013, 3 days in 2014). Important controversies remain on the independent impact of air pollution on coronary events. For instance, in the large England and Wales Myocardial Ischemia National Audit project gathering 202550 STEMI (ST Elevation Myocardial Infarction) and 322198 NSTEMI (Non-ST Elevation Myocardial Infarction), no association between $\mathrm{NO}_{2}$ and STEMI could be established. Conversely, in NSTEMI, a positive association between daily $\mathrm{NO}_{2}$ concentration and NSTEMI could be demonstrated that persisted following adjustment for $\mathrm{O}_{3}$ and $\mathrm{PM}_{2.5}$. In this trial, a $0.27 \%$ increase in risk per $10 \mu \mathrm{g} / \mathrm{m}^{3}$ increase in $\mathrm{NO}_{2}$ concentration could be established [11]. Accordingly, in the work by Milojevic and coworkers, positive association between $\mathrm{NO}_{2}$ (lags 0-4) with NSTEMI could also be demonstrated, with a more pronounced estimated risk $\left(0.68 \%\right.$ per $10 \mu \mathrm{g} / \mathrm{m}^{3}$ increase) [16]. Another recent report has underlined a noxious synergy between road traffic noise and $\mathrm{NO}_{2}$ with a prominent role for traffic noise [17]. Other meta-analyses have emphasized the view that $\mathrm{NO}_{2}$ concentrations were closely associated with hospital admissions or stroke mortality [18]. Up to now, only few reports have explored the pathological pathways linking $\mathrm{NO}_{2}$ exposure to plaque rupture and thrombus formation. In the work by Mills, exposure of healthy volunteers to air pollutant including $\mathrm{NO}_{2}$ induced a swift impairment of endothelial function and endogenous fibrinolysis [19]. Other pathways include systemic inflammatory response, oxidative 
stress, and enhanced platelet activation, key mediators in plaque formation, rupture, and subsequent thrombus formation [20,21].

Other data has highlighted the seasonality of air pollution and coronary events [22-25]. Interestingly, the winter predominance of coronary events was even described in the south hemisphere when winter season corresponds to warmer temperatures. Geographically, Strasbourg is located in the Rhine plane bordered by the Vosges and the Black Forest mountain massifs and is frequently affected by the winter inversion phenomenon. In our study, both coronary events and air pollution peaked during the winter. When time and seasonal adjustments were performed, the independent impact of $\mathrm{NO}_{2}$ concentrations on myocardial infarction could not be established. Possible explanations include (i) the limited power of the study (1265 coronary events) when considering the limited specific impact of $\mathrm{NO}_{2}$ exposure ( 0.27 to $0.68 \%$ increase per $10 \mu \mathrm{g} / \mathrm{m} 3$ increase), (ii) the collinearity of the data, and (iii) unrecorded confounding factors. Among them, the impact of cold weather conditions, concurrent respiratory infections, the decrease in the number of hours of sunshine, and stress conditions including catecholamine activation possibly involved in the triggering of coronary events deserve further investigation [26].

Limitations of the study: This analysis shares the inherent limitations of any retrospective registry. Demographics and clinical characteristics could not be studied. The coronary event was a composite criterion that comprised 6 categories, including myocardial infarction. STEMI and NSTEMI were not individualized. Individual exposure to air pollution was not assessed. Confounding factors, which possibly explained seasonal variation such as inflammatory markers or concomitant respiratory infections were not investigated. Finally, possible variations in the population during the holidays (especially in summer) were not taken into account.

\section{Conclusions}

In Strasbourg, France, higher daily coronary events were recorded when $\mathrm{NO}_{2}$ concentrations peaked above $>30 \mu \mathrm{g} / \mathrm{m}^{3}$. After time adjustment, no independent impact of the air pollution on coronary events could be determined. The specific role of cold weather conditions, concurrent respiratory infections, or the decrease in the number of hours of sunshine on coronary events onset deserves further investigation.

Author Contributions: Conceptualization, T.B., O.M. and B.V.; methodology, M.M. (Marie Moitry), T.B., O.M. and B.V.; validation, O.M. and T.B.; formal analysis, E.S., N.M., M.M. (Marie Mielcarek), M.M. (Marie Moitry) and O.M.; investigation, B.V.; resources, P.R., M.M. (Marie Moitry), B.M., T.R., P.O., O.M. and L.J.; data curation, B.M., M.M. (Marie Moitry), L.J., P.O., O.M. and B.V.; writing—original draft preparation, B.V.; writing—review and editing, O.M. and B.V.; visualization, O.M., T.B. and B.V.; supervision: O.M.; project administration, O.M.; funding acquisition, O.M. All authors have read and agreed to the published version of the manuscript.

Funding: This work was supported by GERCA “Groupe pour l’Enseignement et la Recherche Cardiologique en Alsace".

Conflicts of Interest: The authors declare no conflict of interest.

\section{References}

1. Liu, H.; Tian, Y.H.; Xiang, X.; Sun, K.; Juan, J.; Song, J.; Cao, Y.Y.; Xu, B.B.; Hu, Y.H. Air Pollution and Hospitalization for Acute Myocardial Infarction in China. Am. J. Cardiol. 2017, 120, 753-758. [CrossRef] [PubMed]

2. Lee, M.W.; Choi, B.G.; Kim, S.W.; Rha, S.-W.; Shim, M.S.; Kim, D.J.; Seo, S.H.; Oh, D.J.; Jeonh, M.H. Air Pollution and Short-Term Clinical Outcomes of Patients with Acute Myocardial Infar on. Clin. Exp. Pharmacol. Physiol. 2017, 44, 631-638. [CrossRef] [PubMed]

3. Garelnabi, M.; Uzoigwe, J.C.; Prum, T.; Bresnahan, E. The Emerging Role of Outdoor and Indoor Air Pollution in Cardiovascular Disease. N. Am. J. Med Sci. 2013, 5, 445-453. [CrossRef] [PubMed]

4. Lelieveld, J.; Evans, J.S.; Fnais, M.; Giannadaki, D.; Pozzer, A. The Contribution of Outdoor Air Pollution Sources to Premature Mortality on a Global Scale. Nature 2015, 525, 367-371. [CrossRef] [PubMed] 
5. Xu, M.; Guo, Y.; Zhang, Y.; Westerdahl, D.; Mo, Y.; Liang, F.; Pan, X. Spatiotemporal Analysis of Particulate Air Pollution and Ischemic Heart Disease Mortality in Beijing, China. Environ. Health 2014, 13, 109. [CrossRef] [PubMed]

6. Bourdrel, T.; Bind, M.-A.; Béjot, Y.; Morel, O.; Argacha, J.-F. Cardiovascular Effects of Air Pollution. Arch. Cardiovasc. Dis. 2017, 110, 634-642. [CrossRef]

7. Bhaskaran, K.; Hajat, S.; Haines, A.; Herrett, E.; Wilkinson, P.; Smeeth, L. Effects of Air Pollution on the Incidence of Myocardial Infarction. Heart 2009, 95, 1746-1759. [CrossRef]

8. Rasche, M.; Walther, M.; Schiffner, R.; Kroegel, N.; Rupprecht, S.; Schlattmann, P.; Schulze, P.C.; Franzke, P.; Witte, O.W.; Schwab, M.; et al. Rapid Increases in Nitrogen Oxides Are Associated with Acute Myocardial Infarction: A Case-Crossover Study. Eur. J. Prev. Cardiol. 2018, 25, 1707-1716. [CrossRef]

9. Collart, P.; Dubourg, D.; Leveque, A.; Sierra, N.B.; Coppieters, Y. Short-Term Effects of Nitrogen Dioxide on Hospital Admissions for Cardiovascular Disease in Wallonia, Belgium. Int. J. Cardiol. 2018, 255, $231-236$. [CrossRef]

10. Vidale, S.; Arnaboldi, M.; Bosio, V.; Corrado, G.; Guidotti, M.; Sterzi, R.; Campana, C. Short-Term Air Pollution Exposure and Cardiovascular Events: A 10-Year Study in the Urban Area of Como, Italy. Int. J. Cardiol. 2017, 248, 389-393. [CrossRef]

11. Barbara, K.B.; Atkinson, R.W.; Milojevic, A.; Heal, M.R.; Doherty, R.M.; Armstrong, B.G.; Mackenzie, L.A.; Vieno, M.; Lin, C.; Wilkinson, P. Myocardial Infarction, ST-Elevation and Non-ST-Elevation Myocardial Infarction and Modelled Daily Pollution Concentrations: A Case-Crossover Analysis of MINAP Data. Open Heart 2016, 3, e000429. [CrossRef]

12. Comparateur de Territoire-Commune de Strasbourg (67482). Available online: https://www.insee.fr/fr/ statistiques/1405599?geo=COM-67482 (accessed on 6 March 2018).

13. MONICA Manual. Available online: https://thl.fi/publications/monica/manual/ (accessed on 8 April 2018).

14. Bard, D.; Kihal, W.; Schillinger, C.; Fermanian, C.; Segala, C.; Glorion, S.; Arveiler, D.; Weber, C. Traffic-Related Air Pollution and the Onset of Myocardial Infarction: Disclosing Benzene as a Trigger? A Small-Area Case-Crossover Study. PLoS ONE 2014, 9, e100307. [CrossRef] [PubMed]

15. Bilan_de_la_Qualite_de_2.pdf. Available online: http://www.atmo-alsace.net/medias/produits/Bilan_de_la_ qualite_de_2.pdf (accessed on 5 April 2018).

16. Milojevic, A.; Wilkinsoon, P.; Armstrong, B.; Bhaskaran, K.; Smeeth, L.; Hajat, S. Short-Term Effects of Air Pollution on a Range of Cardiovascular Events in England and Wales: Case-Crossover Analysis of the MINAP Database, Hospital Admissions and Mortality. Heart 2014, 100, 1093-1098. [CrossRef] [PubMed]

17. Roswall, N.; Raaschou-Nielsen, O.; Ketzel, M.; Gammelmark, A.; Overvad, K.; Olaen, A.; Sorensen, M. Long-Term Residential Road Traffic Noise and NO2exposure in Relation to Risk of Incident Myocardial Infarction-A Danish Cohort Study. Environ. Res. 2017, 156, 80-86. [CrossRef]

18. Short Term Exposure to Air Pollution and Stroke: Systematic Review and Meta-Analysis. Available online: https://www-ncbi-nlm-nih-gov.scd-rproxy.u-strasbg.fr/pmc/articles/PMC4373601/ (accessed on 9 April 2018).

19. Nicholas, L.M.; Törnqvist, H.; Robinson, S.D.; Gonzalez, M.; Darnley, K.; MacNee, W.; Boon, N.A.; Donaldson, K.; Blomberg, A.; Sandstrom, T.; et al. Diesel Exhaust Inhalation Causes Vascular Dysfunction and Impaired Endogenous Fibrinolysis. Circulation 2005, 112, 3930-3936. [CrossRef]

20. Rückerl, R.; Greven, S.; Ljungman, P.; Aalto, P.; Antoniades, C.; Bellander, T.; Berglind, N.; Chrysohoou, C.; Forastiere, F.; Jacquemin, B.; et al. Air Pollution and Inflammation (Interleukin-6, C-Reactive Protein, Fibrinogen) in Myocardial Infarction Survivors. Environ. Health Perspect. 2007, 115, 1072-1080. [CrossRef]

21. Andrew, J.L.; Lundbäck, M.; Mills, N.L.; Faratian, D. Diesel Exhaust Inhalation Increases Thrombus Formation in Man. Eur. Heart J. 2008, 29, 3043-3051. [CrossRef]

22. Gibelin, P. Météo et saisons influencent-elles notre cœur? La Presse Médicale 2015, 44, 821-827. [CrossRef]

23. Trends of Myocardial Infarction Morbidity and Its Associations with Weather Conditions-ScienceDirect. Available online: https:/www-sciencedirect-com.scd-rproxy.u-strasbg.fr/science/article/pii/S1010660\$ times\$14000524 (accessed on 4 April 2018).

24. Nagarajan, V.; Fonarow, G.C.; Ju, C.; Pencina, M.; Laskey, W.K.; Maddox, T.M.; Hernandez, A.; Bhatt, D.L. Seasonal and Circadian Variations of Acute Myocardial Infarction: Findings from the Get with the Guidelines-Coronary Artery Disease (GWTG-CAD) Program. Am. Heart J. 2017, 189, 85-93. [CrossRef] 
25. Swampillai, J.; Wijesinghe, N.; Sebastian, C.; Devlin, G.P. Seasonal Variations in Hospital Admissions for ST-Elevation Myocardial Infarction in New Zealand. Cardiol. Res. 2012, 3, 205-208. [CrossRef]

26. Smeeth, L.; Thomas, S.L.; Hall, A.J.; Hubbard, R.; Farrington, P.; Vallance, P. Risk of Myocardial Infarction and Stroke after Acute Infection or Vaccination. N. Engl. J. Med. 2004, 351, 2611-2618. [CrossRef] [PubMed] 